Gut, 1985, 26, 1008-1013

\title{
Studies on the mechanism of action of dioctyl sodium sulphosuccinate in the human jejunum
}

\author{
K J MORIARTY, M J KELLY, R BEETHAM, AND M L CLARK \\ From the Departments of Gastroenterology and Chemical Pathology, St Bartholomew's Hospital, London
}

SUMmaRY An intestinal perfusion technique has been used to investigate the mechanism of action of the laxative, dioctyl sodium sulphosuccinate, in the human jejunum. Dioctyl sodium sulphosuccinate stimulated net secretion of water, sodium, chloride and potassium and inhibited net absorption of glucose and bicarbonate. These changes in water and solute transport were partially reversed by administration of indomethacin $(4 \mathrm{mg} / \mathrm{kg} /$ day orally for three days), which suggests that they are mediated in part by endogenous prostaglandins.

Dioctyl sodium sulphosuccinate (DSS) is a laxative which has been shown to stimulate water and electrolyte secretion in mammalian intestine. ${ }^{1-4}$ Possible mechanisms contributing to this secretagogue action include active electrolyte secretion, mediated by increased intracellular concentrations of cyclic AMP, ${ }^{2}$ impaired solute absorption due to mucosal cell damage, ${ }^{56}$ altered mucosal permeability $^{24}$ and deranged intestinal motility. ${ }^{78}$ These effects of DSS may be produced by a direct action of the laxative on the intestinal mucosa, or they may be mediated by endogenous prostaglandins, synthesised and released locally from the intestine after contact with DSS. ${ }^{3}$

The purpose of the present studies was to investigate the mechanism of action of DSS in the human jejunum, and in particular to assess the role of endogenous prostaglandins in mediating changes in water and solute transport.

\section{Methods}

SUBJECTS

Ten healthy subjects gave written informed consent for the study which was approved by the Ethical Committee of St Bartholomew's Hospital, London.

INTESTINAL PERFUSION

After an eight hour fast, each subject swallowed a double lumen intestinal perfusion tube, incorporating a proximal occluding balloon, a $30 \mathrm{~cm}$ test

Address for correspondence: Dr K J Moriarty, Department of Medicine. Hope Hospital, Salford M6 8HD.

Received for publication 15 November 1984 segment and a mercury bag. ${ }^{9}$ The tube was positioned under fluoroscopic control such that the balloon was situated at the ligament of Treitz with the infusion orifice located in the first $5 \mathrm{~cm}$ of jejunum. Using a peristaltic pump, the test solutions at $37^{\circ} \mathrm{C}$ were perfused through the infusion orifice at a rate of $15 \mathrm{ml} / \mathrm{min}$. The control perfusate (control) contained $(\mathrm{mmol} / \mathrm{l}): \mathrm{Na}, 149 ; \mathrm{Cl}, 124 ; \mathrm{HCO}_{3}, 25 ;$ glucose, 10; polyethylene glycol (PEG), $2.5 \mathrm{~g} / \mathrm{l}$ and 1 $\mu \mathrm{Ci} / 1\left[{ }^{14} \mathrm{C}\right] \mathrm{PEG}$ as a non-absorbable marker. The composition of the DSS-containing perfusate (DSS) was identical, except that it also contained 0.5 $\mathrm{mmol} / \mathrm{l}$ DSS. The osmolality of both perfusates was $290 \mathrm{mosmol} / \mathrm{kg}$. The solutions were continuously gassed throughout each experiment with $95 \% \mathrm{O}_{2-}$ $5 \% \mathrm{CO}_{2}$. After a 30 minute equilibration period, during which the aspirates were discarded, three successive 10 minute aspirates were collected by siphonage. Aliquots were taken for immediate bicarbonate estimation and samples for the determination of other solute concentrations were stored at $-20^{\circ} \mathrm{C}$ before analysis. The net transport of water and solutes for each perfusate were calculated as the mean of the values measured in each of the three aspirates.

\section{EXPERIMENT 1}

In all 10 subjects, the control and DSS solutions were perfused in random order to determine their effects on water and solute transport.

In order to assess whether the action of DSS was reversible, the order of perfusion in three of these subjects was control, DSS, control for a final 80 minute period, during which sequential 10 minute 
aspirates were collected.

In six subjects, the mean transit time for the transport of luminal fluid through the test segment for the control and DSS perfusates was calculated, under steady state conditions, by injecting a one millilitre $(50 \mathrm{~g} / \mathrm{l})$ bolus of bromsulphalein through the infusion orifice and measuring the appearance and subseguent disappearance of the dye from the aspirates. $^{10}$

\section{EXPERIMENT 2}

In six of the 10 subjects studied in experiment 1 , repeat perfusion with both the control and DSS perfusates was carried out after the administration of the cyclooxygenase inhibitor, indomethacin (4 $\mathrm{mg} / \mathrm{kg}$ body wt/day orally for three days). This was taken in four divided doses, the last dose being ingested one hour before the repeat perfusion was started.

\section{CHEMICALS}

The following chemicals were used: Dioctyl sodium sulphosuccinate (Sigma Chemical Company, St Louis, Missouri, USA); Indomethacin (Merck, Sharp \& Dohme Ltd, Hoddesdon, Herts).

\section{ANALYSIS OF SAMPLES AND CALCULATIONS}

The concentrations of $\left[{ }^{14} \mathrm{C}\right] \mathrm{PEG}$, glucose, sodium, potassium, chloride, bicarbonate, urea, and the alkaline phosphatase activities in the aspirates were measured. $\left[{ }^{14} \mathrm{C}\right] \mathrm{PEG}$ was measured in an LKB 1210 Ultrobeta liquid scintillation counter. ${ }^{11}$ Glucose was determined using a modified glucose oxidase method. ${ }^{12}$ Sodium and potassium concentrations were measured using an EEL 227 flame photometer (Evans Electroselenium Ltd, Halstead, Essex) and chloride by an EEL chloridometer. Bicarbonate concentrations were measured as total $\mathrm{CO}_{2}$ using a Corning $965 \mathrm{CO}_{2}$ analyser (Corning Ltd, Halstead, Essex), whilst urea concentrations were measured on a Technicon II system. Alkaline phosphatase activity was measured spectrophotometrically. This enzyme liberates p-nitrophenol (PNP) from the substrate p-nitrophenylphosphate (PNPP), in the presence of the co-factors, magnesium, zinc and cobalt. ${ }^{13}$

Absorption rates of water and solutes from the test segment were calculated from their measured concentrations in the perfusate and aspirates. ${ }^{14} \mathrm{Net}$ absorption $(+)$ indicates a net transfer of water or solute from the lumen; net secretion $(-)$ indicates net transfer of water or solute into the lumen.

\section{STATISTICAL METHODS}

Statistical comparisons were done using the Student's $t$ test and the Mann-Whitney U test. ${ }^{15}$

\section{Results}

EFFECT OF DIOCTYL SODIUM SULPHOSUCCINATE ON NET WATER AND SOLUTE TRANSPORT

(Table 1)

Dioctyl sodium sulphosuccinate stimulated net secretion of water $(p<0.001)$, sodium $(p<0.001)$, chloride $(p<0.001)$ and potassium $(p<0.001)$, inhibited net absorption of bicarbonate $(p<0.01)$ and glucose $(p<0.01)$, but had no effect on net transport of urea.

EFFECT OF INDOMETHACIN ON WATER AND SOLUTE TRANSPORT FROM THE CONTROL AND DSS PERFUSATES (Table 2)

Indomethacin pretreatment had no significant effect on net water and solute transport from the control solution, but it partially reversed the effect of DSS on jejunal water and solute transport, enhancing net absorption of water $(p<0 \cdot 01)$, sodium $(p<0 \cdot 01)$, chloride $(p<0.01)$, bicarbonate $(p<0.01)$ and glucose $(p<0.02)$, and reducing net potassium secretion $(p<0 \cdot 05)$. The effects of DSS were, however, not completely inhibited by indomethacin pretreatment, in that a comparison between DSS post-IND and control pre-IND reveals that the net absorption of water $(p<0.01)$, sodium $(p<0.01)$, chloride $(p<0.01)$, bicarbonate $(p<0.05)$ and glucose $(\mathrm{p}<0.02)$ were significantly inhibited and net potassium secretion $(\mathrm{p}<0.05)$ was significantly greater from DSS post-IND.

\section{REVERSIBILITY OF THE EFFECTS OF DIOCTYL} SODIUM SULPHOSUCCINATE

In the three subjects in whom the control solution was perfused both before and after the DSS perfusate, net absorption of water during the second control perfusion returned to values which did not differ significantly from those observed during the

Table 1 Effect of dioctyl sodium sulphosuccinate on net water and solute transport

\begin{tabular}{lcc}
\hline & Control & DSS \\
\hline Water & $+174 \pm 9 \cdot 0$ & $-120 \pm 19 \cdot 4^{*}$ \\
Sodium & $+27 \cdot 3 \pm 1 \cdot 6$ & $-16 \cdot 3 \pm 2 \cdot 9^{*}$ \\
Chloride & $+18 \cdot 2 \pm 1 \cdot 6$ & $-19 \cdot 2 \pm 2 \cdot 7^{*}$ \\
Potassium & $-1 \cdot 62 \pm 0 \cdot 06$ & $-2 \cdot 53 \pm 0 \cdot 08^{*}$ \\
Bicarbonate & $+11 \cdot 6 \pm 0 \cdot 7$ & $+2 \cdot 4 \pm 1 \cdot 1^{+}$ \\
Glucose & $+8 \cdot 44 \pm 0 \cdot 1$ & $+6 \cdot 73 \pm 0 \cdot 36^{\dagger}$ \\
Urea & $-1 \cdot 46 \pm 0 \cdot 17$ & $-1 \cdot 50 \pm 0 \cdot 20$ \\
\hline
\end{tabular}

Net transport of water is expressed in $\mathrm{ml} / 30 \mathrm{~cm} / \mathrm{h}$ and of solutes in $\mathrm{mmol} / 30 \mathrm{~cm} / \mathrm{h} .+=$ absorption, $-=$ secretion. Results are the mean \pm SEM of observations in 10 subjects. ${ }^{*} p<0.001,+p<0.01$. $p$ values refer to the level of significance of the difference between the control and DSS perfusion solutions. 
Table 2 Effect of indomethacin (IND) on net water and solute transport

\begin{tabular}{|c|c|c|c|c|}
\hline & $\begin{array}{l}\text { Control } \\
\text { pre-IND }\end{array}$ & $\begin{array}{l}\text { Control } \\
\text { post-IND }\end{array}$ & $\begin{array}{l}D S S \\
\text { pre-IND }\end{array}$ & $\begin{array}{l}D S S \\
\operatorname{post-IND}\end{array}$ \\
\hline Water & $+175 \pm 13 \cdot 6^{i 1}$ & $+222 \pm 28.4$ & $-132 \pm 25$ & $+65 \pm 18^{*}$ \\
\hline Sodium & $+27 \cdot 9 \pm 2 \cdot 5^{11}$ & $+33 \cdot 6 \pm 5 \cdot 4$ & $-18 \cdot 1 \pm 3 \cdot 5$ & $+10.8 \pm 1.6^{*}$ \\
\hline Chloride & $+19 \cdot 8 \pm 2 \cdot 5^{\prime \prime}$ & $+22 \cdot 4 \pm 4 \cdot 1$ & $-18 \cdot 8 \pm 3 \cdot 8$ & $+3.7 \pm 2.5^{*}$ \\
\hline Potassium & $-1.67 \pm 0.088^{\circ}$ & $-1 \cdot 63 \pm 0 \cdot() 8$ & $-2 \cdot 51 \pm 0 \cdot 1$ & $-2 \cdot 14 \pm 0 \cdot 1 \pm$ \\
\hline Bicarbonate & $+11 \cdot 7 \pm 1 \cdot 1^{\circ}$ & $+13 \cdot 7 \pm 1 \cdot()$ & +()$\cdot 7 \pm 1 \cdot 3$ & $+8 \cdot 7 \pm 0.6^{*}$ \\
\hline Glucose & $+8 \cdot 51+0 \cdot 13^{b}$ & $+8 \cdot 64 \pm 0 \cdot 11$ & $+6 \cdot 6 \pm 0.5$ & $+8 \cdot(1 \pm 0.2 \dagger$ \\
\hline Urea & $-1 \cdot 54 \pm() \cdot 20$ & $-1 \cdot 86 \pm 0 \cdot 19$ & $-1 \cdot 52+0 \cdot 12$ & $-1 \cdot 80 \pm 0 \cdot 12$ \\
\hline
\end{tabular}

Net transport of water is expressed in $\mathrm{ml} / 30 \mathrm{~cm} / \mathrm{h}$ and of solutes in $\mathrm{mmol} / 30 \mathrm{~cm} / \mathrm{h} .+=$ absorption, $-=$ secretion. Results are the mean \pm SEM of observations in six subjects. ${ }^{*} p<0 \cdot 01,{ }^{\dagger} p<0 \cdot 02, \ddagger p<0 \cdot 05$, where the $p$ values refer to the level of significance of the differences between DSS pre-IND and DSS post-IND. ${ }^{a} p<0 \cdot 01,{ }^{b} p<0 \cdot 02,{ }^{c} p<0 \cdot 05$, where the $p$ values refer to the level of significance of the differences between control pre-IND and DSS post-IND.

first control period (Figure). This occurred within $30-40$ minutes of discontinuation of the DSS perfusion and was paralleled by the net movement of glucose.

\section{EFFECT OF DSS ON ALKALINE PHOSPHATASE} ACTIVITY

The effect of DSS on the luminal release of the brush border enzyme, alkaline phosphatase, as determined by the liberation of p-nitrophenol (PNP) from the substrate p-nitrophenylphosphate (PNPP), is shown in Table 3. The release of alkaline phosphatase into the luminal fluid was significantly

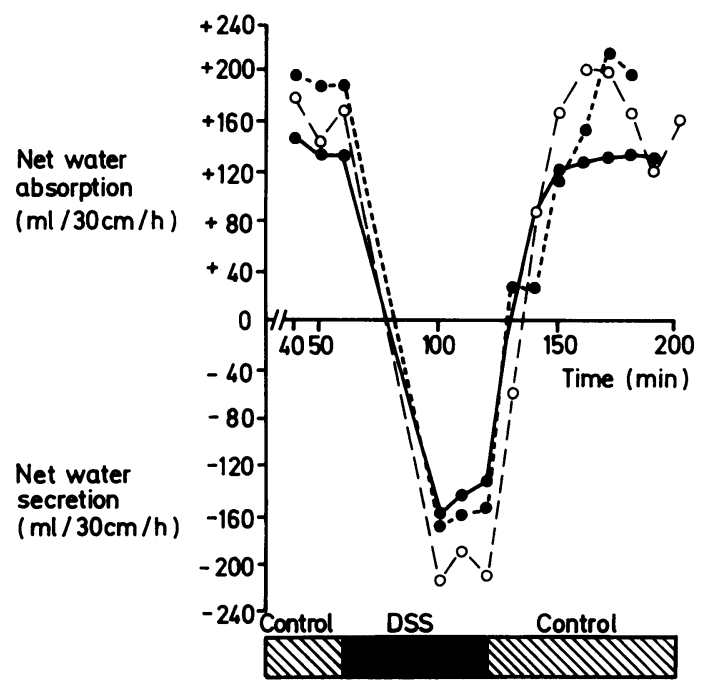

Figure Three subjects were perfused with the control and DSS solutions as shown. Net water absorption during the second control period returned to initial control values, indicating rapid functional recovery of the jejunal mucosa after DSS perfusion. greater from the DSS perfusate than from the control solution, both before $(p=0 \cdot 004)$ and after $(p=0.047)$ indomethacin pretreatment. Indomethacin had no significant effect on alkaline phosphatase activity in either the control or DSS perfusates.

EFFECT OF DSS ON JEJUNAL MEAN TRANSIT TIME

There was no significant difference between the mean transit time of luminal fluid through the test segment during the control $(5 \cdot 6 \pm 1 \cdot() \mathrm{min})$ and DSS $(4 \cdot 7 \pm 0 \cdot 8 \mathrm{~min})$ perfusions.

\section{Discussion}

Dioctyl sodium sulphosuccinate was perfused at a concentration of $0.5 \mathrm{mmol} / \mathrm{l}$ because it has been calculated that concentrations of this order are achieved in the jejunum if the recommended therapeutic dose is ingested. ${ }^{1}$ At this concentration. DSS stimulated net secretion of water, sodium, chloride, and potassium and inhibited net absorption of glucose and bicarbonate in the human jejunum in vivo. In vitro, DSS produced an increase in the short-circuit current and PD and decreased net sodium absorption across the intestinal mucosa. ${ }^{2}$ Mucosal concentrations of cyclic AMP were increased after exposure to the secretagogue, and it is now known that, in vitro, cyclic AMP inhibits

Table 3 Effect of DSS on alkaline phosphatase activity in the aspirates

\begin{tabular}{llll}
\hline & Control & DSS & $p$ \\
\hline pre-IND & $40 \cdot 0 \pm 6 \cdot 7$ & $86 \cdot 1 \pm 11 \cdot 8$ & $0 \cdot(004$ \\
post-IND & $47 \cdot 4 \pm 6 \cdot 5$ & $95 \cdot 5 \pm 20 \cdot 7$ & $0 \cdot(047$ \\
\hline
\end{tabular}

Alkaline phosphatase activity is measured in $\mu \mathrm{mol} / / \mathrm{p}$-nitrophenol liberated by the aspirates $/ 30 \mathrm{~cm} / \mathrm{min}$. Results are the mean $\pm \mathrm{SEM}$ of six observations. $p$ values refer to the level of significance of the differences between the control and DSS perfusates. 
coupled sodium chloride entry ${ }^{16}$ and stimulates active chloride secretion, ${ }^{17}$ while in vivo, cyclic AMP-mediated processes inhibit bicarbonate absorption in the human jejunum. ${ }^{18}$ The changes induced by DSS in the present study in sodium, chloride and bicarbonate movement, which provide the driving force for the passive secretion of water and potassium, suggest that they may be mediated by increased intracellular cyclic AMP.

The mechanism by which DSS increases cyclic AMP concentrations in the intestinal mucosa is controversial, because of species variation in enzyme activities. In the rat, DSS activated adenylate cyclase in the colon but not in the jejunum, whilst the activity of cyclic AMP-dependent phosphodiesterase in both the small and large intestine was unchanged. ${ }^{19}$ Dioctyl sodium sulphosuccinate, however, had no effect on adenylate cyclase activity in either human small or large intestinal mucosa, although it competitively inhibited cyclic AMPdependent phosphodiesterase activity in colonic mucosa. ${ }^{20}$ These effects on mucosal cyclic AMP may be due to a direct action of DSS or could be mediated by prostaglandins of the $E$ series released locally from the intestine following contact with DSS. ${ }^{3} 19$

The effects of DSS on water and solute transport were partially reversed when perfusion was repeated after indomethacin pretreatment. The mechanism of this antisecretory action of indomethacin is, however, uncertain. In the present study, indomethacin had no significant effect on water or solute transport from the control solution, indicating that its inhibition of the secretory effects of DSS was not caused by the stimulation of an independent absorptive process.

Indomethacin inhibits fluid secretion mediated by cyclic AMP, ${ }^{21-24}$ and also inhibits cyclic AMPdependent protein kinase, ${ }^{25}$ which suggests that its site of action is distal to cyclic AMP production. Intestinal secretion mediated by both cyclic GMP $^{22} 26$ and calcium ${ }^{22}$ is also inhibited by indomethacin, indicating that the drug might inhibit stimulus-secretion coupling generally.

Because it has been proposed that arachidonic acid metabolites, including prostaglandins, are involved in the regulation of all forms of stimulussecretion coupling, ${ }^{27-30}$ then blockade of arachidonic acid metabolism, particularly via the cyclooxygenase pathway, may be the mechanism for the antisecretory effect of indomethacin. ${ }^{30}$ Indomethacin has been shown to inhibit the biosynthesis of prostaglandins in the intestine ${ }^{31}{ }^{32}$ and it is possible that this inhibition, particularly of $\mathrm{PGE}_{2}$, may be the mechanism by which indomethacin inhibits fluid secretion. ${ }^{33-35}$
Doses of indomethacin of the order used in the present study have been shown to inhibit endogenous prostaglandin synthesis by about $90 \%$, as evidenced by the reduced urinary excretion of the major metabolite of $\mathrm{PGE}_{1}$ and $\mathrm{PGE}_{2}, 7 \alpha$-hydroxy5,11-di-keto tetranorprostane-1,16-dioic acid. ${ }^{36}$ The finding that indomethacin pretreatment did not completely reverse the effects of DSS on water and solute transport suggests that mechanisms other than prostaglandin release may be involved in mediating its action.

Glucose absorption may be inhibited by histological damage to the jejunal mucosa. In the rat, concentrations of DSS of up to $2 \mathrm{mmol} / \mathrm{l}$ in the jejunum ${ }^{1}$ and up to $6 \mathrm{mmol} / \mathrm{l}$ in the large intestine ${ }^{2}$ did not produce histological damage, whilst in the human jejunum, $2 \mathrm{mmol} / \mathrm{l}$ DSS caused increased loss of DNA into the aspirates, although it was not clear whether this finding represented increased cell loss because of mucosal damage or desquamation secondary to fluid secretion. ${ }^{4}$ In the present study, DSS increased the output into the lumen of the brush border enzyme, alkaline phosphatase, and this increase was unaffected by indomethacin treatment. This suggests that DSS increases the rate of desquamation of epithelial cells, particularly villi, into the lumen, which might contribute to the reduced glucose absorption. Mucosal damage may also lead to the release of arachidonic acid with the formation of prostaglandins. ${ }^{37}$ The rapid recovery of both water and glucose absorption after discontinuation of DSS, however, argues against a major contribution of mucosal damage to the effects of DSS on glucose and water transport.

Changes in mucosal permeability have been implicated in the pathophysiology of bile acid- and laxative-induced intestinal secretion. ${ }^{38}$ Sodium ricinoleate, a long chain fatty acid similar to DSS, increases mucosal permeability in the rabbit intestine, as evidenced by increased secretion of urea into the lumen. ${ }^{39}$ In the present study, luminal urea secretion was similar for the control and DSS perfusates, both before and after indomethacin. The absence of a change in urea permeability, however, does not exclude changes in mucosal permeability to other macromolecules induced by DSS.

Likewise, the effects of DSS on water and solute transport were not contributed to by a decrease in the mean transit time of luminal fluid along the perfusion segment. Results obtained in the jejunal perfusion system, however, cannot be extrapolated to whole gut transit time, and DSS has been shown to slow the transit of both a meal and dye through the intestine. ${ }^{78}$

In summary, DSS is a potent secretagogue in the human jejunum. Its mechanism of action is multifac- 
torial, including a stimulation of electrolyte secretion, decreased absorption of glucose and bicarbonate and a possible minor contribution from mucosal damage. These effects are likely to be caused by a combination of a direct effect of DSS on the jejunal mucosa and an indirect effect of DSS through the release of endogenous prostaglandins.

KJM was in receipt of a Medical Research Council Training Fellowship. MJK is funded by the Joint Research Board, St Bartholomew's Hospital. This work was also supported by the Peel Medical Research Trust. We sincerely thank Mrs J Rostron for typing the manuscript.

\section{References}

1 Saunders DR, Sillery J, Rachmilewitz D. Effect of dioctyl sodium sulfosuccinate on structure and function of rodent and human intestine. Gastroenterology 1975; 69: $380-6$.

2 Donowitz $\mathbf{M}$, Binder $\mathbf{H J}$. Effect of dioctyl sodium sulfosuccinate on colonic fluid and electrolyte movement. Gastroenterology 1975; 69: 941-50.

3 Beubler E, Juan $\mathrm{H}$. Effect of ricinoleic acid and other laxatives on net water flux and prostaglandin $\mathrm{E}$ release by the rat colon. J Pharm Lond 1979; 31: 681-5.

4 Bretagne JF, Vidon $\mathrm{N}$, L'Hirondel C, Bernier JJ. Increased cell loss in the human jejunum induced by laxatives (ricinoleic acid, dioctyl sodium sulphosuccinate, magnesium sulphate, bile salts). Gut 1981; 22: 264-9.

5 Gullikson GW, Cline WS, Lorenzsonn V, Benz L, Olsen WA, Bass P. Effects of anionic surfactants on hamster small intestinal membrane structure and function: relationship to surface activity. Gastroenterology 1977; 73: 501-11.

6 Sund RB, Jacobsen DN. In vivo reversibility of the jejunal glucose and cation transport alteration caused by intraluminal surfactants in the rat. Acta Pharmacol Toxicol 1978; 43: 339-45.

7 Lish PM, Dungan KW. Peristaltic-stimulating and fecal-hydrating properties of dioctyl sodium sulfosuccinate, danthron and cascara extracts in the mouse and rat. J Am Pharm Assoc 1958; 47: 371-5.

8 Lish PM. Some pharmacologic effects of dioctyl sodium sulfosuccinate on the gastrointestinal tract of the rat. Gastroenterology 1961; 41: 580-4.

9 Sladen GE, Dawson AM. Further studies on the perfusion method for measuring intestinal absorption in man: the effects of a proximal occlusive balloon and a mixing segment. Gut 1970; 11: 947-54.

10 Dillard RL, Eastman H. Fordtran JS. Volume-flow relationship during the transport of fluid through the human small intestine. Gastroenterology 1965; 49: $58-66$.

11. Wingate DL, Sanberg RJ, Phillips SF. A comparison of stable and ${ }^{14} \mathrm{C}$-labelled polyethylene glycol as volume indicators in the human jejunum. Gut 1972; 13: 812-5.
12 Lloyd JB, Whelan WJ. An improved method for enzymic determination of glucose in the presence of maltose. Analyt Biochem 1969; 30: 467-70.

13 Eichholz A. Structural and functional organization of the brush border of intestinal epithelial cells. III. Enzymic activities and chemical composition of various fractions of tris-disrupted brush borders. Biochim Biophys Acta 1967; 135: 475-82.

14 Sladen GE, Dawson AM. An evaluation of perfusion techniques in the study of water and electrolyte absorption in man: the problem of endogenous secretions. Gut 1968; 9: 530-5.

15 Snedecor GW, Cochran WG. Statistical methods. 7th ed. Ames, Iowa: Iowa State University Press, 1980.

16 Frizzell RA, Field M, Schultz SG. Sodium-coupled chloride transport by epithelial tissues. Am J Physiol 1979; 236: F1-F8.

17 Field M, Fromm D, Al-Awqati Q, Greenough WB III. Effect of cholera enterotoxin on ion transport across isolated ileal mucosa. J Clin Invest 1972; 51: 796-804.

18 Davis GR, Santa Ana CA, Morawski SG, Fordtran JS. Effect of vasoactive intestinal polypeptide on active and passive transport in the human jejunum. J Clin Invest 1981: 67: 1687-94.

19 Rachmilewitz D, Karmeli F. Effect of bisacodyl (bis) and dioctyl sodium sulfosuccinate (DSS) on rat intestinal prostaglandin $\mathrm{E}_{2}\left(\mathrm{PGE}_{2}\right)$ content, Na-K-ATPase and adenyl cyclase activities. Gastroenterology 1979; 76: 1221 .

20 Simon B, Kather $H$. Interaction of laxatives with enzymes of cyclic AMP metabolism from human colonic mucosa. Eur J Clin Invest 1980; 10: 231-4.

21 Wald A, Gotterer GS, Rajendra GR, Turjman NA, Hendrix TR. Effect of indomethacin on cholerainduced fluid movement, unidirectional sodium fluxes, and intestinal cAMP. Gastroenterology 1977; 72: 106-10.

22 Smith PL, Blumberg JB, Stoff JS, Field M. Antisecretory effects of indomethacin on rabbit ileal mucosa in vitro. Gastroenterology 1981; 80: 356-65.

23 Jacoby $\mathrm{HI}$, Marshall $\mathrm{CH}$. Antagonism of cholera enterotoxin by anti-inflammatory agents in the rat. Nature 1972; 235: 163-5.

24 Giannella RA, Gots RE, Charney AN, Greenough WB, Formal SB. Pathogenesis of salmonella-mediated intestinal fluid secretion. Activation of adenylate cyclase and inhibition by indomethacin. Gastroenterology 1975; 69: 1238-45.

25 Kantor $\mathbf{H}$, Hampton $\mathbf{M}$. Indomethacin in submicromolar concentrations inhibits cyclic AMP-dependent protein kinase. Nature 1978; 276: 841-2.

26 Madsen GL, Knoop FC. Inhibition of the secretory activity of Escherichia coli heat-stable enterotoxin by indomethacin. Infect Immun 1978; 22: 143-7.

27 Cuthbert AW, Margolius HS. Kinins stimulate net chloride secretion by the rat colon. Br J Pharmacol 1982, 75: 587-98.

28 Manning DC, Snyder SH, Kachur JF, Miller RJ, Field $M$. Bradykinin receptor-mediated chloride secretion in intestinal function. Nature (Lond) 1982; 299: 256-9.

29 Musch MW, Miller RJ, Field M, Siegel M. Lipoxygenase metabolites of arachidonic acid: potential 
mediators of electrolyte secretion. Gastroenterology 1982; 82: 1257.

30 Musch MW, Kachur JF, Miller RJ, Field M. Bradykinin-stimulated electrolyte secretion in rabbit and guinea pig intestine: involvement of arachidonic acid metabolites. J Clin Invest 1983; 71: 1073-83.

31 Beubler E, Juan H. PGE-release, blood flow and transmucosal water movement after mechanical stimulation of the rat jejunal mucosa. NaunynSchmiedeberg's Arch Pharmacol 1978; 305: 91-5.

32 Ferreira SH, Herman AG, Vane JR. Prostaglandin production by rabbit isolated jejunum and its relationship to the inherent tone of the preparation. $\mathrm{Br} J$ Pharmacol 1976; 56: 469-77.

33 Bukhave K, Rask-Madsen J. Prostaglandins and chronic diarrhoea: methodological problems. Scand J Gastroenterol 1979; 14: suppl 53: 67-71.

34 Bukhave K, Rask-Madsen J. Saturation kinetics applied to in vitro effects of low prostaglandin $E_{2}$ and $F_{2 \alpha}$ concentrations on ion transport across human jejunal mucosa. Gastroenterology 1980; 78: 32-42.

35 Rask-Madsen J, Bukhave K. Prostaglandins and intestinal secretion. In: Turnberg LA, ed. Intestinal secretion. Welwyn Garden City: Smith, Kline and French Laboratories Limited, 1983: 76-83.

36 Hamberg $M$. Inhibition of prostaglandin synthesis in man. Biochem Biophys Res Commun 1972; 49: 720-6.

37 Rachmilewitz D. Prostaglandins and diarrhea. Dig Dis Sci 1980; 25: 897-9.

38 Binder HJ. Pharmacology of laxatives. Ann Rev Pharmacol Toxicol 1977; 17: 355-67.

39 Gaginella TS, Chadwick VS, Debongnie JC, Lewis JC, Phillips SF. Perfusion of rabbit colon with ricinoleic acid: dose-related mucosal injury, fluid secretion, and increased permeability. Gastroenterology 1977; 73: 95-101. 